Brock Education, Vol 18, 2008

\title{
Trends in Canadian faculties of education: An overview of graduate programs, curricular offerings, exit requirements, and modes of delivery
}

\author{
Jason Brent Ellis: University of Windsor, Canada \\ Jonathan G. Bayley: University of Windsor, Canada \\ Carla Abreu Ellis: University of Windsor, Canada
}

\begin{abstract}
This research investigated universities registered with the Association of Universities and Colleges of Canada (AUCC) whose primary instructional language was English. A content analysis was performed on university web pages related to the following content: (a) frequency of graduate programs being offered, (b) types of degrees being offered, (c) frequency and variation of program of study offerings, (d) variation of exit requirements, and (e) modalities of course delivery. This research provides an overview and analysis of graduate level programs, more precisely Masters and Doctorate degrees, offered through faculties of education in Canada. An understanding of the findings of this research may benefit Canadian university administrative bodies in providing a source in which they may compare findings with their current offerings and programming. Prospective students of graduate programs in education may also benefit from the information provided in this study when choosing a program of study by ameliorating their knowledge of current programs, curriculum offerings, and modes of course delivery being offered by faculties of education in Canada.
\end{abstract}

\section{Literature Review}

There has been a significant increase in demand for access to higher education in Canada within the last decade. According to Giroux (2004), enrolment growth in the first few years of the new millennium "outstrips growth in the Canadian population" (p. 85). Giroux further clarifies that "Provinces with the largest population growth over the past few years have seen enrolment increases, but even provinces that are experiencing population declines are witnessing strong enrolment growth" (p. 85). He notes that this growth is principally due to the fact that more high school students are opting to matriculate in university than ever before as a result of a variety of factors including parental pressure to seek a university education and decreased dropout rates in K-12 education.

Universities have traditionally catered to societal needs, although reluctance to institutional change is often noted. Societal changes, both directly and indirectly, affect institutions that "hate to be hurried into change, even though their connection to change (in the form of progress, growth, and prosperity) is one of the most important bases of their self-esteem and public appeal" (Findlay, 2006, p. 415). The Association of Universities and Colleges of Canada (n.d.) states that Canadian universities that are a part of this association are committed to, "the importance of higher education for the individual and for the economic, social and cultural development of society" ( $(4)$. This commitment, required by the AUCC, illustrates the importance placed not solely on the betterment of the individual through the process of higher education but also the condition of fulfilling societal needs in terms of the economic and cultural development of Canada. British Columbia's Ministry of Advanced Education (n. d.) makes this 
dual mission of individual growth and meeting provincial needs through higher education implicit in stating that:

The Ministry's mission for the post-secondary education and training system is to provide leadership and support for a top-notch advanced education and training system that provides all British Columbians with opportunities to develop the skills and knowledge to live productive and fulfilling lives and to contribute to the economic, social and cultural life of the province. ( $(\mathbb{1} 1)$

Marshall (2004) notes that as a result of increased enrolment in Canadian universities in recent years undoubtedly provinces will "continue to approve an array of new degrees and degreegranting institutions to respond to this demand" (p. 91).

This idea of institutions meeting societal needs demands an analysis of who decides on what gets taught and changed, in terms of programming in Canadian higher education. Marshall (2004) notes that there is no federal management to education in Canada and therefore "each of the ten provinces and three territories established their own methods to manage and control the credentials offered by post-secondary institutions" (p. 71). Marshall further observes, in terms of the consistency of quality of education between institutions, that if an institution was approved by the representative provincial government, "it was deemed to be accredited. Since only recognized public universities were traditionally provided the legislation to offer degrees, the quality of the Canadian degree was consistent (and of generally high quality) from coast to coast" (p. 72).

Marshall (2004) also draws attention to the fact that Provincial accreditation bodies also control label usage in higher education as to what institutions can offer degrees and constitute universities. In recent years the Association of Universities and Colleges of Canada has taken a much larger role in the accreditation process in that,

In Canada, which does not have a national system of institutional accreditation and where education ... falls within the jurisdiction of the provincial governments, membership in the Association, coupled with the appropriate provincial legislation, is generally accepted in lieu of institutional accreditation. (AUCC, n.d., \2)

This means that the AUCC has become, as Marshall (2004) coins it, the de facto body for accrediting new degree granting institutions in Canada.

In terms of who decides program offerings within universities, and how instruction is designed and delivered, Buchbinder and Rajagopal (1996) note that Canadian universities have "exclusive jurisdiction over admission standards, curricula and the granting of degrees" (p. 283). In a keynote address at the 2004 Asian Development Bank Conference on University Governance in Indonesia, Dr. Michael Stevenson (2004), President and Vice-Chancellor of Simon Fraser University, identified the process ensuring autonomy in the Canadian academy: In Canada, the Acts under which our universities are established entrench the bicameral powers of university Senates and grant them more or less complete control over academic policy. That is to say: what shall be taught, who shall teach it, and how it shall be taught. In British Columbia these fundamental powers of university autonomy reside in the Senate elected entirely by the university itself. No outside appointees or outside positions have authority over academic policy. (\$ 20).

Stevenson further notes that because of the bicameral nature of university governance in Canada it "creates a climate in which government respects university autonomy because it is embedded in legislation that in turn sets limits to what government, and even the executive or the Board appointed by the government, can do with respect to universities" ( $($ 22). 
The literature would indicate that Canadian universities are being called to fulfill the societal demand of increased access to higher education. Institutions of higher education will attempt to meet these needs through offering new programs and wider access by working within the parameters set forth by accrediting bodies. It is important to note that curricular and program offerings in Canadian universities are decided autonomously by the institutions themselves.

\section{Methodology}

A content analysis was performed in the 2005/2006 academic year of Graduate College and Faculty of Education web pages for all universities registered with the Association of Colleges and Universities of Canada whose primary language of instruction was English. Patton (1990) defines content analysis as "the process of identifying, coding, and categorizing the primary patterns in the data" (p. 381). In this manner, researchers in this study looked at the data displayed online by universities and identified "themes that seem meaningful to the producers of each message" (Berg, 2004, p. 272). Units and categories were constructed and evolved over the course of the analysis. Berg (2004) clarifies this process in stating that, "Content analysis involves the interaction of two processes: specification of the content characteristics ... being examined and explicit rules for identifying and recording these characteristics" (p. 275). Thus, content characteristics that were identified for this research involved the following themes: (a) graduate programs being offered by faculties of education; (b) types of degrees being offered; (c) program offerings; (d) types of exit requirements, and; (e) modalities of course delivery. A data set was constructed using an inductive process of analysis, as discussed by Berg (2004), from information available online. Where information was ambiguous or incomplete, institutional representatives were contacted in order to gather further information and create a complete picture of graduate studies.

\section{Findings}

\section{Graduate Program Offerings in Canada}

Of the 92 universities registered with the Association of Colleges and Universities of Canada at the time this research was performed, 72 (78.3\%) were identified as having their instructional language primarily being English. Less than half, or 33 (45.8\%) of these 72 universities were identified as offering graduate programs in education.

\section{Degrees Offered}

An analysis of the data revealed a considerable variation in the types of degrees being awarded by graduate programs in Canadian faculties of education. The most frequent type of Masters level degree being awarded was that of the Masters of Education (M.Ed.) awarded by 30 $(90.9 \%)$ universities surveyed. The following breakdown provides an overview of additional degree types offered by Canadian institutions: Masters of Arts (M.A.), in education, were offered by $10(30.3 \%)$ institutions, Masters of Science (M.Sc.) were offered by three (9.1\%) institutions, Masters of Counselling (M.C.) were offered by three (9.1\%) institutions, Masters of Adult Education (M.A.E.) were offered by two (6.1\%) institutions, Masters of Human Resource Development (M.H.R.D) were offered by one (3.0\%) institution, Masters of Educational Technology (M.E.T.) were offered by one (3.0\%) institution, Masters of Library and Information Sciences were offered by one (3.0\%) institution, and Masters of Distance Education (M.D.E.) were offered by one (3.0\%) institution. At a doctorate level, 20 (60.6\%) institutions currently offer Doctoral of Philosophy (Ph.D.) degrees and 4 (12.1\%) offer Education Doctorate (Ed.D.) degrees. 


\section{Programs Offered}

The variation in programs of study being offered through faculties of education was quite extensive; 37 curriculum categories were identified as being offered by institutions. Broader subject categories were constructed from grouping frequencies for curricular subject; 11 distinct subject areas were defined. These 11 curriculum subject areas were identified as program offering in: Arts in Education, Human Services in Education, Exceptionality, Specific Populations in Education, Foundation Areas of Education, Curriculum and Instruction, Human Sports and Kinetics, Language Arts, Leadership and Governance, Specific Curriculum Areas, and Educational Support Services. Please see table 1.1 for a complete breakdown of frequencies of programs of study.

Table 1.1

\begin{tabular}{|c|c|c|}
\hline Programs of study & $f$ & $\%$ \\
\hline \multicolumn{3}{|l|}{ Arts in Education } \\
\hline Arts Education & 7 & 21.2 \\
\hline Music Education & 3 & 9.1 \\
\hline \multicolumn{3}{|l|}{ Human Services in Education } \\
\hline Counselling & 17 & 51.5 \\
\hline Educational Psychology & 11 & 33.3 \\
\hline Rehabilitation Counselling & 2 & 6.1 \\
\hline Human Resource Development & 1 & 3 \\
\hline \multicolumn{3}{|l|}{ Exceptionality } \\
\hline Special Education & 6 & 18.2 \\
\hline Gifted Education & 3 & 9.1 \\
\hline School Psychology & 3 & 9.1 \\
\hline \multicolumn{3}{|l|}{ Specific Populations in Education } \\
\hline Adult Education & 7 & 21.2 \\
\hline Higher Education & 4 & 12.1 \\
\hline Distance Education & 3 & 9.1 \\
\hline Early Childhood & 3 & 9.1 \\
\hline Indigenous Education & 3 & 9.1 \\
\hline \multicolumn{3}{|l|}{ Foundation Areas of Education } \\
\hline Education Studies & 14 & 42.4 \\
\hline Society, Culture and Politics & 11 & 33.3 \\
\hline Measurement and Research & 4 & 12.1 \\
\hline Philosophy of Education & 3 & 9.1 \\
\hline History of Education & 2 & 6.1 \\
\hline \multicolumn{3}{|l|}{ Curriculum and Instruction } \\
\hline Curriculum & 19 & 57.6 \\
\hline Instruction & 9 & 27.3 \\
\hline Development, Learning \& Cognition & 6 & 18.2 \\
\hline \multicolumn{3}{|l|}{ Human Sports and Kinetics } \\
\hline Human Kinetics & 3 & 9.1 \\
\hline Physical Education & 3 & 9.1 \\
\hline Health Professional Education & 1 & 3 \\
\hline \multicolumn{3}{|l|}{ Language Arts } \\
\hline Language and Literacy & 8 & 24.2 \\
\hline English as a Second Language & 5 & 15.2 \\
\hline
\end{tabular}


Modern Language Education

2

Leadership and Governance

Leadership and Policy Studies

Educational Administration

Additional Curriculum Areas

Math Education

Science Education

Social Studies Education

English Language Arts

Home Economics

Educational Support Services

Educational Technology

Librarianship
16

11

6

5

3

2

2

10

3
6.1

48.5

33.3

18.2

15.2

9.1

6.1

6.1

30.3

9.1

Programs of Study by Subject Area in Frequencies and Percentages

\section{Exit Requirements}

Exit requirements were looked at exclusively for the Masters-level of graduate studies due to the fact that less standardization of exit requirements occurred than at a doctorate level. For the purpose of this paper exit requirements were defined as any culminating activity, capstone or otherwise that was designated by either the Graduate College or the Faculty of Education as being necessary to fulfill the degree requirement. The exit requirement as a culminating activity was seen to have the intentionality of placing onus on the student to demonstrate a synthesis of all knowledge acquired during the duration of graduate studies (such as cumulative examinations), prove adequacy of research skills (such as theses and research projects), show competency in academic writing (such as the major paper), or; perhaps demonstrate a combination of several of the activities listed (such as a Portfolio). Categories were constructed for the types of exit requirements in place in Canadian institutions which included the production and defence of a thesis, portfolio, project or paper, and; the writing of comprehensive examinations. Thirty-two of the 33 universities surveyed provided access to exit requirement criteria online; analysis indicated that $32(97 \%)$ institutions offered a thesis option as an exit requirement; $22(66.7 \%)$ offered the possibility of a project or major paper based exit option, $10(30.3 \%)$ offered the possibility of a comprehensive exam and, five $(15.2 \%)$ institutions offered the possibility of completing a portfolio as the exit requirement. It was observed that $12(36.4 \%)$ institutions currently offered a course-based option with an exiting capstone activity (non-thesis) as an option towards achieving a Masters degree.

\section{Delivery Methods}

Thirty-one of the 33 universities surveyed provided access to information regarding mode of course delivery online. Delivery methods of course materials in Master's programs of graduate education varied; it was observed that no $(0 \%)$ universities chose a delivery method that was entirely web base (online), whereas 20 (64.5\%) institutions offered a traditional (classroom, onsite and off-site) form to delivering instruction and $11(35.5 \%)$ universities had instituted a "mixed method" of instructional delivery, incorporating both web-based and traditional instruction.

\section{Discussion}

When attempting to answer the question, what is being offered at the graduate level in Canadian Faculties of Education, the simple answer would be a great deal. Current trends 
would lead one to believe that Faculties of Education are taking an "everything goes" stance on what can be contained under the blanket of education and instruction. According to Buchbinder and Rajagopal (1996), universities in Canada are "governed by provincial statutes and are funded by federal and provincial governments, as well as by student fees" (p. 283). They further state that Canadian universities have "exclusive jurisdiction over admission standards, curricula, and the granting of degrees" (p. 283), but qualify that, "even though they are autonomous, they are influenced to act in the interest of Canadian society through the use of buffer bodies (between governments and universities) and Boards of Governors" (p. 283). Having established that Canadian universities have the autonomy to offer what they want within the context of societal needs as a whole, the curriculum found in the universities surveyed ranged from a spectrum of traditional foundations of theory (e.g. Philosophy of Education and History of Education) to new areas of curriculum such as Health Professional Education, Human Resource Development, and Human Kinetics. Perhaps this range is a reflection of the ideas noted by Buchbinder and Rajagopal (1996), in that Canadian universities are offering programs that meet local societal demand in the workforce.

Types of degrees being offered across Canada at a Masters level also appear to be expanding; offerings seem to bridge across a much wider range such as the Masters of Human Resource Development (M.H.R.D.), Masters of Educational Technology (M.E.T.), and Masters of Distance Education (M.D.E.) providing additional options to the traditional Masters of Education and Masters of Arts awards. Marshall (2004) has indicated that the proliferation of new degree offerings is symptomatic of the increasing demand for higher education in the market place. He notes that because of this, there has been a noted increase in non-university delivered degrees, and disparity in the fact that "the provincial-level degree accreditation processes and the university-level degree granting standards, as represented in the membership criteria for AUCC, are no longer aligned" (p. 69). Marshall's concern rests in the premise that because of this lack of provincial and federal alignment of the granting of awards there is a certain danger to consumers in that "different degree accreditation processes have led to different degrees with different meaning and value to the student" (p. 70) and thus the connotation of caveat emptor (buyer beware) has become a forewarning for prospective students shopping for an education.

But perhaps the question is not one of how institutions can offer different awards but more a question of why. Smith (2005) recently found that, in the Province of Manitoba, meeting societal need in "programming has been the more favoured category [in program approval], leading to a greater focus on labour market orientation in new university programming" (p. 111). Levin (1999) furthers this argument by observing that, in an effort to sustain themselves financially, colleges and universities in Canada "have turned to the marketplace, and in Canada this means the private and the public sector, for resources, for models of management and work, and for programming direction and instructional content" (p. 397). This has direct implications on the nature of community and higher education institutions as being a highly symbiotic, reciprocal relationship.

The notion of innovations of new specialty degree types contrasts with this paper's findings that methods of delivery appear to still be mostly focused on traditional classroom instruction, although there does appear to be a movement towards a mixed methods of instructional delivery. Pan (2003) discussed the various advantages of online (web-based) learning as having the potential to reach a wider range of students in terms of convenience, feedback, learner control, contact, interactivity, and accessibility. However, Pan (2003) identified several instructional pitfalls through this delivery mode related to issues of rights and copywrite, 
requisite technology abilities of the instructors, quality of design of e-lectures, and the challenge of designing an effective outcome assessment of e-learning. Perhaps these confounding factors of web-based learning are why traditional classroom instruction in Canadian universities is highly embraced.

\section{Conclusion}

It appears that a great deal of diversity exists in programs being offered by faculties of education in Canadian universities. This diversity could be seen as a direct reflection of local community and societal needs being met by higher education institutions. This could be further emphasised in drawing attention to the fact that universities have had to enter into reciprocal relationships with communities in order to secure funding to be sustainable educational environments. This expansion of program and degree offerings contrasts with the finding that delivery methods of instruction most often take the form of tradition classroom learning, rather that online (web-based) instructional methods. The reasons for this phenomenon could stem from the inability of institutions to procure instructors with technology skill requisite to implement such an instructional method as well as other confounding qualities such as copywrite and design issues. 


\section{References}

Association of Universities and Colleges of Canada. (n. d.). Quality assurance at Canadian universities. Retrieved February 24, 2006 from http://www.aucc.ca/qa/index_e.html.

Association of Universities and Colleges of Canada. (n. d.). AUCC membership criteria. Retrieved February 24, 2006 from http://www.aucc.ca/qa/membership_crit/index_e.html.

Berg, B.L. (2004). Qualitative research methods for the social sciences. Toronto: Pearson Education, Inc.

British Columbia Ministry of Advanced Education. (n. d.). Post secondary education division. Retrieved February 24, 2006 from http://www.aved.gov.bc.ca/branches/psed/.

Buchbinder, H. and Rajagopal, P. (1996). Canadian universities: The impact of free trade and globalization. Higher Education, 31(3), 283-299.

Findlay, L. M. (2006). A Long Eclipse: The Liberal Protestant Establishment and the Canadian University, 1920-1970, and: Knowledge Matters: Essays in Honour of Bernard J. Shapiro (review). The University of Toronto Quarterly, 75(1), 415-416.

Giroux, R. J. (2004). Enrolment demand versus accessibility at Canada's Universities. The Canadian Journal of Higher Education, 34(1), 83-96.

Levin, J. S. (1999). Missions and structures: Bringing clarity to perceptions about globalization and higher education in Canada. Higher Education, 37, 377-399.

Marshall, D. (2004). Degree accreditation in Canada. The Canadian Journal of Higher Education, 34(2), 69-96.

Pan, W. S. (2003). The challenges of teaching statistics in the current technology environment. Journal of American Academy of Business, 3, 351-354.

Patton, M. Q. (1990). Qualitative evaluation and research methods. London: Sage Publications.

Smith, D. (2005). Liberal arts vs. applied programming: The evolution of university programs in Manitoba. The Canadian Journal of Higher Education, 35(1), 111-132.

Stevenson, M. (2004). University Governance and Autonomy: Problems in Managing Access, Quality and Accountability. Keynote address to ADB conference on University Governance Denpasar, Indonesia, retrieved February 24, 2006 from http://www.sfu.ca/pres/president/speeches/20045.html. 